\title{
Investigations and explorations in the mathematics classroom ${ }^{1}$
}

\author{
João Pedro da Ponte \\ jponte@fc.ul.pt \\ Grupo de Investigação DIFMAT-Didáctica e Formação de Professores de Matemática \\ Centro de Investigação em Educação e Departamento de Educação \\ Faculdade de Ciências da Universidade de Lisboa, Portugal
}

\begin{abstract}
In Portugal, since the beginning of the 1990s, problem solving became increasingly identified with mathematical explorations and investigations. A number of research studies have been conducted, focusing on students' learning, teachers' classroom practices and teacher education. Currently this line of work involves studies from primary school to university mathematics. This perspective impacted the mathematics curriculum documents that explicitly recommend teachers to propose mathematics investigations in their classrooms. On national meetings many teachers report experiences involving students' doing investigations and indicate to use regularly such tasks in their practice. However, this still appears to be a marginal activity in most mathematics classes, especially when there is pressure for preparation for external examinations (at grades 9 and 12). International assessments such as PISA and national assessments (at grades 4 and 6) emphasize tasks with realistic contexts. They reinforce the view that mathematics tasks must be varied beyond simple computational exercises or intricate abstract problems but they do not support the notion of extended explorations. Future developments will show what paths will emerge from these contradictions between promising research and classroom reports, curriculum orientations, professional experience, and assessment frameworks and instruments.
\end{abstract}

Keywords. Problem-solving, Mathematical investigations, Mathematical explorations, Curriculum, Assessment, Learning.

Resumo. Em Portugal, desde o princípio dos anos 90, a resolução de problemas tornou-se cada vez mais identificada com explorações e investigações matemáticas. Diversos estudos de investigação foram realizados tendo por foco as aprendizagens dos alunos, as práticas lectivas dos professores e a formação de professores. Presentemente, esta linha de trabalho envolve estudos desde o 1. ${ }^{\circ}$ ciclo do ensino básico até ao ensino superior. Esta perspectiva teve impacto nos documentos curriculares de Matemática que recomendam explicitamente aos professores que proponham investigações matemáticas nas suas salas de aula. Nos encontros nacionais muitos professores relatam experiências envolvendo os alunos a realizar investigações e indicam usar regularmente estas tarefas na sua prática. Contudo, este tipo de trabalho parece ser ainda marginal na maioria das aulas de Matemática, especialmente quando existe pressão para preparação para exames externos (no 9. ${ }^{\circ}$ e $12 .^{\circ}$ anos de escolaridade). Avaliações internacionais tais como PISA e avaliações nacionais (nos $4 .^{\circ}$ e e $6 .^{\circ}$ anos de escolaridade) enfatizam tarefas com contextos realísticos. Estas avaliações reforçam a perspective que as tarefas matemáticas devem ser vistas para além dos simples exercícios de cálculo ou problemas abstractos complicados mas não apoiam a noção de explorações aprofundadas. Os desenvolvimentos futuros mostrarão que caminhos poderão emergir destas contradições entre investigação e relatórios da sala de aula prometedores, orientações curriculares, experiência profissional, e sistemas e instrumentos de avaliação.

Palavras-chave. Resolução de problemas, Investigações matemáticas, Explorações matemáticas, Currículo, Avaliação, Aprendizagem.

\footnotetext{
${ }^{1}$ Ponte, J. P. (2007). Investigations and explorations in the mathematics classroom. ZDM, 39(5-6), 419430 .
} 
Explorations and investigations in the mathematics classroom

This article presents mathematical explorations and investigations as a particular approach to problem solving that has been developing in Portugal since the beginning of the 1990s. In a first section it shows how the notions of mathematical investigation and exploration gradually emerged from the reflection about the role of problems and problem solving in mathematics education. The second part of the paper is devoted to research on mathematical investigations, considering students' ability to investigate, students' mathematics learning, students' attitudes and conceptions, and teachers' practices and teacher education. The third and fourth parts of the paper are devoted to the influence of the curriculum and of the assessment system on professional practices regarding mathematical explorations and investigations. The paper concludes indicating open issues for future research regarding this curriculum approach.

\section{Mathematical investigations as a special form of problem solving}

The notion of problem solving gained prominence in Portuguese mathematics education at the beginning of the 1980s. In a paper presented at one of the first mathematics education meetings carried out in the country, Ponte and Abrantes (1982), influenced by the ideas of Pólya (1945) in How to solve it and by NCTM's (1980) Agenda for action, presented the notion of problem as a "question in which the students do not have a ready made routine process to solve it, but that stimulates their curiosity and their will to work on it" (p. 205). At the same time, these authors suggested that, in solving a problem, the student "is called to have an active participation. He/she must be the mathematician. He/she must face each new situation, think for him/herself, take his/her decisions and evaluate the work done" (pp. 201-2). They do not use explicitly the word "investigation", but, like Hadamard (1945), they suggest that the student may carry out an activity similar to that of the professional mathematician.

Since that time, problem solving has been at the centre of curriculum debates and inspired several local curriculum development experiences, often undertaken as academic studies within doctoral or master degree programs. It also received an important impulse with the NCTM's (1989) Curriculum and evaluation standards for school mathematics. When the new basic education (grades 1-9) mathematics syllabi were written, problem solving become the "central axis" of mathematics teaching and learning (Ministério da Educação, 1991a, 1991b). Some years later, it was also indicated 
Explorations and investigations in the mathematics classroom

as an important orientation of the new secondary education (grades 10-12) mathematics syllabi (Ministério da Educação, 1997). With minor modifications, all these syllabi are still being used today.

The wide variety of tasks that may be presented as problems led mathematics educators to feel uneasy regarding this concept. In an attempt to contribute to its clarification, Abrantes (1998) distinguished among seven different kinds of problems exercise, word problem, problem to put in equation, problem to prove, problem to discover, real life problem, problematic situation, and situation - and analysed their educational value. In his view, the most interesting problems are the last three - exactly those that he considered to be more ignored in mathematics teaching practice. One notes a similarity between the ideas of "problematic situation" and "investigation activity". Also in this period, a seminar that took place in Vila Nova de Milfontes, marking an important moment in the affirmation of a new curricular perspective in Portuguese mathematics education, makes many references to "problems", "problem solving" and "problem formulation" as well as to "exploration, investigation and discovery activities" (APM, 1988, p. 43).

Besides the interest on problem solving, the 1980s also constitute a period of exploration of the potential of information and communication technologies in mathematics teaching - particularly, the LOGO language and spreadsheets and, later on, graphics calculators and dynamic geometry software. One aspect of these technologies that stands up is that - with suitable tasks and micro worlds - they favour an exploratory and investigative approach to the teaching and learning of mathematics. In fact, in the context of LOGO micro worlds, there were many studies where the notions of investigation and problem often appeared interconnected.

At the beginning of the 1990s, the notion problem was still highly problematic to mathematics educators, as one can see in several papers of the First Mathematics Education Research Meeting that took place at Ericeira. For example Fernandes (1992), reflecting on the status of research on problem solving, indicated that there are "difficulties resulting from interpretations, that vary widely among researchers, associated to the most used concepts on problem solving" (p. 45). Among these problematic concepts he included the notion of problem itself. And Boavida (1992) went as far as saying that: 
Explorations and investigations in the mathematics classroom

... If one aims that problem solving is the organizing focus of mathematics education [one must question] several concepts, among which the notions of problem and problem solving that are not understood in the same way by different authors (original emphasis). (p. 106)

The concept of mathematical investigation is discussed in depth in a paper by Ponte and Matos (1992) that comes back to the idea that in an investigation "students are put in the role of mathematicians" (p. 239). For the authors, this is what happens when students seek to understand a complex situation and to discover patterns, relations, similarities and differences in order to arrive at generalizations. In their perspective, mathematical investigations include a variety of situations, from complex tasks that may require some time to solve to relatively simple questions that often arise in the classroom. This paper claims that:

Mathematical investigations share common aspects with other kinds of problem solving activities. They involve complex thinking processes and require a high involvement and a creative stand from the student. However, they also involve some distinctive features. While mathematical problems tend to be characterized by well defined givens and goals, investigations are much looser in that respect. The first task of the student is to make them more precise, a common feature that they share with the activity of problem posing. (p. 239)

The authors also indicated several characteristic moments of the process of mathematical investigation, such as formulating questions, making and testing conjectures, and, eventually, proving them. In this paper, mathematical investigations appeared for the first time clearly as a kind of task distinct from problems. It is this notion of mathematical investigation that became the reference for the studies developed in the 1990s in Portugal, in particular to the most significant initiative in this area - the Project Mathematics for All. For this project, the integration of investigation activities in the mathematics curriculum stands on a number of reasons:

- They constitute an essential part of the mathematics work, being intimately related to the nature of the mathematics activity and to the process of producing knowledge in this field - and if we want students to develop a general view of mathematics, then it is necessary that they get involved in investigation activities.

- They favour the involvement of students in the work that takes place in the mathematics classroom, necessary for significant learning. 
- They provide multiple entry points for students at different levels of mathematics ability, since most investigation tasks may be pursued in several ways and with different levels of depth.

- They stimulate a holistic way of thinking that goes beyond the application of knowledge or isolated procedures and implies the mobilization of ideas from different areas of mathematics.

- They can be constructed for of all curriculum topics, often based on elements of their historical development.

- They deal with complex thinking processes but reinforce the learning of facts, concepts and procedures, making an important contribution to their consolidation. (Abrantes, Ponte, Fonseca and Brunheira, 1999)

As Ponte, Brocardo and Oliveira (2003) indicate, we carry out a mathematical investigation when we formulate our own questions and seek to respond to them in a well argued and rigorous way. For these authors, in teaching, in learning and in teacher education contexts, to investigate does not necessarily means to deal neither with problems at the frontier of knowledge nor with very difficult problems. In a wider perspective, to investigate means to work from questions in which we are interested, that at beginning we usually regard as confusing, but that we are able to clarify and study in an organized way.

These authors discuss in detail how on a mathematical investigation one begins with a very general question or from a set of little structured information from which one seeks to formulate a more precise question about which one produces a number of conjectures. Afterwards, one tests those conjectures. If some one finds counterexamples, those conjectures may be may be improved or be put completely aside. In this process, sometimes new questions are formulated and the initial questions are abandoned, completely or in part. The conjectures that resist to several tests gain credibility, stimulating a proof that, if achieved, will confer mathematical validity.

Both problem solving and investigations call for imagination and creativity. They require abilities that are much beyond simple computation and memorization of definitions and procedures. These abilities, sometimes called "higher order abilities", are related to communication, critical spirit, modelling, data analysis, logical deduction and to several metacognitive processes (Abrantes, 1994). The emphasis in this kind of abilities stands on many arguments, since those that underline their formative role in the intellectual development of the individual and in preparing for a critical and conscious 
citizenship, to those that emphasize the utilitarian side, related to the possible mathematical needs of the jobs of the future.

The term "investigation" may appear to some as intimidating. As a consequence, in practice, often one speaks of "explorations". These are often regarded as tasks that have an open nature but are not as sophisticated as investigations. Of course, the line between explorations and investigations are as blurred as the line between exercises and problems and often these terms are used interchangeably. The important idea is that in both cases the problem is not completely formulated beforehand and the student has a role to play in defining the mathematical question to pursue.

Similar perspectives about the nature of mathematical tasks that teachers may propose in the classroom have been offered by Mason, Burton and Stacey (1982), under the notion of "thinking mathematically", Nohda (1991) with his "open-approach", and more recently Sullivan (1999, in his discussion about "content specific open-ended tasks" and Skovsmose (2001) who speaks of "landscapes of investigation". This perspective also permeates NCTM's (2000) Principles and standards for school mathematics and is quite explicit in many recent issues of this organization's professional journals.

\section{Research on mathematical investigations}

The notion of mathematical investigation as a basis for students' learning originated a series of studies carried out in different school levels. These studies concern three main questions: (i) the development of students' ability to do investigations; (ii) the promotion of students' mathematics learning; and (iii) the influence of these activities in students' attitudes and conceptions. In parallel, there were studies about teachers' practices and teacher education. This section reviews the main results of the studies about students' learning and provides a brief characterization of other current studies.

\section{Students' ability to investigate}

A study of Segurado (1997, 2002), carried out in a grade 6 class, gives indications about students' ability in doing mathematical investigations. This study involved five tasks, about one each month. According to the teacher, the students 
developed the ability to observe, establish relationships, conjecture, test, justify, and argue. In the third task they revealed a noticeable investigative stance, formulating and testing conjectures. In the last task it was still more evident that the students had begun understanding the importance of organizing data, searching regularities, formulating conjectures, validating them through examples, and defending their discoveries with arguments. The author concludes:

It is possible to provide students of this school level a mathematical experience of doing investigations. Students are able to approach the tasks and move in the direction of becoming confident in their abilities, of enlarging their ability to solve and formulate problems and of communicating and reasoning mathematically. (Segurado, 2002, p. 72)

Brocardo (2002) undertook a study during a full school year, in collaboration with another teacher, in a grade 8 class, using thirteen investigation tasks. Concerning the understanding that students show of this kind of tasks, she indicates that they, initially, had tendency to transform the first data collection experiences in an end of itself and showed some difficulty in viewing the investigation as a whole. However, as students carried out more tasks, they begun relating the initial observations and seeking to clarify the focus of the investigation, ending up with a good understanding of this kind of work.

In a previous study, Junqueira (1996) carried out a teaching experiment in a grade 9 class of another teacher, using Cabri-Geomètre. The experience concerned plane geometry, and used 24 classes (of 50 minutes) and followed a non directive approach. The author notes that, at the beginning, students' work was not much productive and concludes that "the proposal to investigate some construction in a very open way, without an explicit goal for the students, seemed to generate some insecurity. They only appropriated these activities when they begun to perceive the conclusions that they might obtain" (p. 94). She indicates that, as time went on, the activity of the students improved its quality: they begun by formulating restricted conjectures, that is, based in the observation of a small number of cases, but the analysis of examples led them to establish more general conjectures.

Researchers have addressed the activity of students at the different stages of a mathematical investigation. Several studies show that students, often, do not feel the need to make the initial question explicit and, other times, change their question without 
noticing, and, consequently, their objective becomes confusing, even for themselves (Ponte and Matos, 1992; Ponte, Ferreira, Brunheira, Oliveira and Varandas, 1998). That also happens when students have a reasonable experience in carrying out investigations and a certain understanding of this process (Brocardo, 2002).

In contrast, the formulation of conjectures does not appear to constitute a problematic issue. Such is indicated, for example, by Ponte et al. (1998), based on a study carried out with students at grades 7-9. These students showed ability to arrive at conjectures integrating geometrical and arithmetical strategies and using variation and generalization. They also were able to modify and adapt conjectures based on counterexamples. However, Brocardo (2002) refers that students have facility in formulating conjectures but frequently they need time to understand their status. Initially they tend to take conjectures as conclusions:

The idea that a mathematics task implies the search for answers/conclusions is very strong in students. (...) The evolution to a really investigative stance in which they formulate conjectures and develop several cycles of confirmation or refutation of these conjectures is a slow process and must be object of explicit work from the teacher. (p. 540)

This author studied in detail the cases of three students and showed that they have tendency to regard an investigation as linear activity in which they (i) collect certain data, (ii) organize them, and (iii) analyse them to take conclusions. Progressively, as they do more investigations, students understand the non linearity of this process and the import and meaning of proving the results. However, this evolution occurs in very diverse rhythms. It is slower in students that have a more mechanistic view of the mathematical activity such as the application of procedures without paying attention to their meaning and implications. In contrast, it is fastest in students with a stronger inclination for carrying out open tasks.

Brocardo (2002) refers that "at an initial phase, the students of this class viewed the proof of their conjectures as an unnecessary 'complication' introduced by the teacher" (p. 544). For them, a conjecture that resists several tests is certainly true, and there is no need to prove it. At a second phase, some students begun understanding what it means to justify a conjecture - something that they regard, however, as exterior to the investigation. Finally, in the last tasks, "most students had the clear notion that it was 
necessary to think abut the proof of their conjectures before finishing the work" (p. 544). The author indicates the fact that the work was continuously done during the year contributed towards this evolution. Brocardo also refers that students tended to improve the quality of their reports as they acquired experience in carrying them out. At the beginning, students mostly presented short sentences, mainly with the results, but later on they produced texts that explain in detail the work they had done.

The studies carried out show that, for many students, doing a mathematical investigation is a new experience. However, supported by the teacher and with the continuation of the work, students get to understand what is an investigation and the role that they are supposed to assume. Some of their difficulties are of general nature. Students begin by using the same strategies that they use to solve exercises and display a linear perspective about the work, going quickly from data collection and organization to formulating conclusions. Other difficulties concern specific aspects of the investigation activity. For example, they tend to give little attention to formulating questions, they take the conjectures quickly as conclusions, and they need some time to understand that these conjectures must be justified. Their natural trend is to consider that the verification of several examples is enough to establish the validity of a statement. However, with the continuation of the experience in doing investigations, most students show significant progresses in overcoming these difficulties. In particular, writing written reports seemed to help them to improve their ability to argue and justify the mathematical results achieved.

\section{Students' mathematics learning}

It is important to know if, as students work in mathematical investigations, they use and consolidate their knowledge of concepts and procedures and experience new learning concerning the general and specific curriculum goals of this discipline.

In her study with grade 6 students, Segurado (2002) indicates that it was quite apparent, "when doing the tasks, the domain that students have of some concepts formerly taught, namely powers, fractions, decimals, prime numbers, divisors, multiples and the use of the calculator" (p. 72). This teacher states: "knowledge acquired gains value for the students when they need it to do the assigned tasks. It was notorious the interest with which these students appropriated some concepts necessary to do the tasks" (p. 72). 
Explorations and investigations in the mathematics classroom

Segurado and Ponte (1998) analyze in detail the case of a student with a high level of achievement in mathematics. They indicate that, as he did the tasks, he showed to have appropriated some concepts and techniques, evidencing security in some aspects but also a surprising difficulty in others. The authors underline that some basic knowledge may be developed in this kind of activity. They also point that if students have only a partial domain of some notions that does not necessarily constitute an impeditive factor for their work.

In this way, doing investigations seems to yield an opportunity for students to use and consolidate their mathematics knowledge, develop their abilities and undertake new learning. However, doing investigations also showed some week points in their mathematics knowledge, sometimes even in concepts ands ideas that could be regarded as well known. Doing investigations in a regular way may help students to develop new mathematics learning, but more studies are necessary to substantiate it. That is the reason why more recent studies are addressing how exploratory and investigative work influence students' learning of particular topics such as algebra and geometry, as I will indicate later on in the paper.

\section{Students' attitudes and conceptions}

Conceptions and attitudes represent the way how people regard the objects and situations and relate to them (Ponte, 1992). Research indicates that students' attitudes and conceptions about mathematics and about mathematics learning frequently interferes in a negative way on how students learn (Ponte, Matos and Abrantes, 1998). One of most frequent conceptions of students is that "mathematics is computation". For example, in a study carried out by Frank (1988), most high achieving grade 6 to 8 students, after participating in two weeks of intensive work on problem solving using computers still consider that mathematics is essentially arithmetical operations. In another paper, Garofalo (1989) refers that the way students usually tackle problems indicates a conception about mathematics thinking that "consists of being able to learn, remember and apply facts, rules, formulas, and procedures" (p. 503). He adds that he way students think is intimately related with their vision of mathematics as a "highly fragmented set of rules and procedures" (p. 503). Studies done in Portugal also suggest that many students see mathematics as consisting on a set of definitions and rules and consider that they learn just by listening to the teachers' explanations and practicing the 
rules (Brocardo, 2001; Segurado, 1997). This research also suggests that the experiences of the students in the classroom influence their attitudes and conceptions.

Such influence on attitudes is apparent in some studies involving mathematical investigations. In fact, many students show their enthusiasm by carrying out these activities as shown, for example, in several narratives of Ponte, Oliveira, Cunha and Segurado (1998). Another author, Brocardo (2002), states that grade 8 students react positively to doing regularly investigations. However, she indicates that, at the beginning of her study "most students got highly involved in exploring tasks [...] but they voiced some unpleasantness as they considered that it was an activity that required high personal perseverance" (p. 554), as the teacher almost always considered their explorations "incomplete".

Brocardo (2002) presents in detail the cases of three students. One student showed from the very beginning interest in exploring non routine tasks. Two other students begun by revealing great difficulty in understanding their role in this kind of tasks, but, at the end of the year they showed to enjoy investigations and were committed in doing them. This author suggests that the success and the receptivity of students to investigations involved movements back and forward, and is intimately related to the forms of organizing the classroom (Brocardo, 2001). She argues that, doing investigations, students' confidence in their abilities becomes stronger.

Similarly to the students' attitudes, their conceptions may also change as they do mathematical investigations. Segurado and Ponte (1998) report the case of Francisco, a grade 6 student who displayed an interesting change of conceptions:

At the beginning of the study, Francisco regards mathematics essentially as a science in which computation has an overriding role. In his view, the teacher constitutes the dominant authority in the classroom, and his/her role is to impart knowledge and assess students. And the students, if they want to learn, need to be attentive in class and to study. However, at this point, Francisco already reveals to enjoy solving problems and shows some originality in the way he regards the tasks that he tackles. That is, his rather limited view of mathematics and mathematics learning is not in complete agreement with his way of being and his personal taste but seems to be largely the result of his adaptation to the school environment and, most specially, to the teaching of mathematics that he has experienced. (p. 33) 
Explorations and investigations in the mathematics classroom

During the year, according to the authors, Francisco shows a high interest in investigation activities. In the first tasks, his reasoning is limited, and he does not go beyond formulating conjectures that he asks the teacher to validate. Progressively, he begins to do tests, to refine conjectures and even to attempt some justifications. In his reasoning he reveals a greater willingness to try new possibilities and he shows increasing autonomy and confidence. The work done in these tasks seems to have helped him to develop his reasoning abilities and his mathematical creativity. Doing these activities led him to assume a new perspective about teaching and learning mathematics. In his new view: (i) mathematics is a science in development, where the investigation process has an important place; (ii) the role of the teacher is to orientate students, motivating them and stimulating them to do their own mathematics; and (iii) tasks must lead the students to learn, but also must generate a stimulating learning environment. Francisco, a young student with a strong inclination towards mathematics, is an uncommon case for whom the tasks proposed and the environment that was created seemed perfectly adequate.

Segurado (1998) also refers to the conceptions of other grade 6 students. At the beginning, and notwithstanding the enthusiasm and commitment with which students received the new tasks, she notes that they experienced several difficulties. She relates these difficulties to the initial conception of these students about mathematics and the role of the teacher. According to the author, the students consider that each mathematics question has one and only one answer and it is the teacher who establishes its validity. Segurado refers that the performance of the pupils evolved during the study, noting an improvement in their capacity to observe, conjecture, test and justify, as well as in their capacity to communicate mathematically, and also indicates a gradual change in their conceptions.

Brocardo (2002) considers that, as a consequence of the work done during the year, the students "established a strong connection between mathematics and mathematical investigations and highlighted the experimental and inductive aspects" (p. 556). The author documents how students moved from a view of mathematics closely related to computation, to a view that integrates "thinking" and problem solving. She states that students, by the end of the year, "consider that they can investigate and discover relationships in mathematics and show clear preference for a learning process in which they are active participants" (p. 560). In her perspective, doing investigations in the classroom helps to establish an environment in which students have a strong 
participation, facilitating their understanding of mathematical processes and ideas. The author concludes that the students evolved in their participation in the classroom discourse, got highly involved in discussing the tasks, extended their investigations and collected ideas for future explorations.

These studies document that students at this school level get often involved with enthusiasm in doing investigations, activity that seems to challenge their curiosity. The studies carried out also show that doing regularly investigations, with discussion and reflection of the results achieved and the processes used may influence students' conceptions in a significant way. Such experience may change their view about the investigative activity, about mathematics, about mathematics learning and the role of the teacher and of the student, developing taste for the discipline and confidence in doing this kind of activity.

\section{Teachers' practices and teacher education}

Research aiming to analyze the nature of the work carried out by the teacher in the classroom when the students do investigations was also carried out (Cunha, 1998; Oliveira, 1998; Ponte, Oliveira, Brunheira, Varandas and Ferreira, 1998). These studies helped to understand the fundamental aspects of teachers' professional knowledge for carrying out mathematical investigations in the classroom. The model of the three phases for the mathematics activity in the classroom - introduction, development, discussion - enabled the identification of the specific problems of each phase. It also called the attention for the decisive importance of the third phase for the construction of shared meanings and the institutionalization of new knowledge. Concerning students' assessment, the studies undertaken show the usefulness of oral and written reports. These studies also indicate that this perspective is rather strange for a large sector of teachers, highly centred in covering the syllabus and in assigning exercises. However, it also showed that investigations have a considerable potential to interest teachers, many of whom have appropriated this idea and use it more or less regularly in their classes.

Other studies sought to understand how this perspective could be introduced in preservice mathematics teacher education (Brunheira, 2002; Fonseca, 2002; Perez, 2002; Ponte, 2001). Results have been encouraging. Some preservice teachers find mathematics investigations strange, when they see them for the first time, but they soon start recognizing their mathematical and educational value. Courses or modules dedicated to this theme were well received by preservice teachers, although 
Explorations and investigations in the mathematics classroom

transdisciplinar approaches that put more emphasis in this working perspective are still to be experimented. Taken together, these studies with inservice and preservice teachers yielded an understanding of the complexity inherent in conducting this kind of activities in the mathematics classroom. They also indicated several elements that are necessary to attend so that preservice teachers develop competence in this area:

1. To have a notion about what a mathematical investigation $i s$, how it is carried out, how its results are validated;

2. To feel a minimum level of confidence and spontaneity in doing an investigation;

3. To have a general view of mathematics that is not restricted to definitions, procedures and rules, but that values this activity;

4. To know how to select and adapt exploratory and investigative tasks adjusted to the his/her classes;

5. To know how to direct pupils in doing investigative work in the classroom, in the phases of introduction, development of the work and final discussion;

6. To have confidence in his/her capacity to manage the class atmosphere and the relations with pupils doing investigations;

7. To develop a perspective about his/her role in curriculum management, attuned with the characteristics of his/her classes.

One must note that the first three points concern preservice teachers' personal relation with mathematical investigations and the last four points relate to their ability to use of investigations in professional practice.

\section{Current research}

The main feature of the studies just mentioned is that they only involve exploration and investigation tasks. Tasks are presented at regular intervals to students (usually one or two each month) and often refer to different mathematical topics (number, geometry, functions...). In these circumstances, it is difficult to document actual learning achieved by the students on these topics. To address this issue, research begun to study the possibility of organizing teaching units with a strong element of explorations and investigations, alongside with other tasks such as exercises and problems. The diversity of tasks aims to yield students with different learning experiences and lead them to attain several curriculum objectives. 
Explorations and investigations in the mathematics classroom

For example, Silvestre (Silvestre and Ponte, 2006) studied learning of proportional reasoning by grade 6 students. She carried out a teaching experiment based in diversified tasks, with emphasis on explorations and realistic and interdisciplinary contexts (youngsters' literature). The teaching experiment lasted for 4.5 weeks ( 3 hours per week) and used worksheets produced by the teacher. Classroom activity was complemented by work in the computer room using Excel and the students had to write reports about the results of their explorations carried out in groups. Students developed scalar or functional strategies based in identifying patterns to solve problems involving proportional relationships and showed to understand the meaning of what they were doing. They regarded tables as a representation system that makes easy to read and understand data.

Other studies focused on algebraic thinking. For example, Branco (Branco and Ponte, 2006) worked with her grade 7 students on a teaching experiment based on tasks addressing the exploration and generalization of patterns and regularities that lasted for 10 weeks (4 hours per week). Working in pairs alternated with collective discussions, where students presented their strategies, discussed them, raised their issues and the main conclusions were developed with everyone's participation. The preliminary results suggest that students developed their own strategies, gave meaning to symbols, constructed their own symbolic representations, and developed a meaningful understanding of algebraic rules and procedures. In another teaching experiment, Matos (Matos and Ponte, 2006) worked with grade 8 students on the topic of functions. The experience included exploratory tasks and problems, involving patterns and regularities (such as functional relationships) aimed at developing students' algebraic thinking, notably in the topics of "Functions" and "First degree equations" and lasted for 8 weeks (3 hours per week). The students showed ability to intuitively identify patterns and regularities and to formulate "pre-generalizations". They also developed meaning for the algebraic language. However, the authors noted that the understanding of fundamental algebraic concepts such as variable is a slow process that requires several years of study.

Geometry was the focus of a study by Candeias (Candeias and Ponte, 2006), who addressed the geometric competence of grade 8 students. The teaching experiment lasted for 14 weeks (3 hours per week) and involved diversified tasks, with emphasis in problems (8 tasks), explorations (13) and investigations (7), in a dynamic geometry environment (The Geometer's Sketchpad) with the students working in pairs. This 
included the study of topics such as lines in the space and the plan (tasks 1-8), decomposition of figures and Pythagoras theorem (tasks 9-17), geometric loci (tasks 821), translations (22-24), and similarity of triangles (25-26). The nature of the tasks, associated to the technological environment, provided a significant learning experience, through which students developed their competence to construct geometric figures, solve problems and investigate geometric situations. In all these studies, the tasks are a major element; however, they are not regarded in isolation but organized in coherent sets.

At the elementary school level there as been also work with mathematical investigations and explorations. For example, a study conducted by Amaral (2003), with students at grades 3 and 4, indicated that they got actively involved in the activities, asking questions and defining goals. These students developed their mathematics communication skills and were able to use their mathematical concepts in new scenarios. In a more recent study, Godinho (2007) showed that the use of investigations with an elementary school student with special educational needs was helpful to promote his individual learning, supporting the development of personal strategies, and influencing positively his notion of mathematics.

At the higher education level, Henriques (Henriques and Ponte, 2006) constructed a teaching unit to develop students' mathematical understanding through the introduction of exploration and investigation tasks in the classroom. This was put into practice in two year 2 classes of the bachelor's degree of Escola Naval (Navy School), where she is the instructor of the Numerical Analysis course. Results show a positive reaction from students regarding the methodology used. In general, students got involved in carrying out the tasks proposed and were able to work in an intuitive way with concepts that they did study previously.

These studies address important mathematical units or courses, in a perspective akin to that proposed by Krainer (1993) with his sets of "powerful tasks" or suggested by Wittmann's (1995) "teaching units" or realistic mathematics education teaching experiments (Gravemeijer, 2005). For some time most of these studies were conducted at a single institution (The University of Lisbon). Nowadays studies dealing with investigative and exploratory approaches are being carried out all across the country. However, they tend to be attached to $\mathrm{PhD}$ and $\mathrm{MS}$ degree programs and are invariably small scale and qualitative studies. The value and feasibility of this approach still needs to face the challenge of large-scale implementation and research. 


\section{Investigations in the Portuguese school mathematics curriculum}

\section{The official curriculum}

The current Portuguese mathematics syllabus of grades 5-6 $\left(2^{\text {nd }}\right.$ cycle of basic education) and 7-8-9 ( $3^{\text {rd }}$ cycle of basic education), both published in 1991, include some direct and indirect references to exploratory and investigative tasks. For example, the syllabus for grades 5-6 states that (Ministério de Educação, 1991a):

- The study of geometry must be based "in activities that allow students to manipulate, observe, compare, discover, construct, draw (...); it is necessary that the student has the opportunity to attempt, to fail, to begin again, to correct" (p. 155);

- The study of number and computations must be based in "carrying out suggestive activities that stimulate students to make conjectures, to will to discover, to discuss strategies..." (p. 158);

- Problem solving, "as an activity, stimulates the spirit of investigation, giving students the opportunity of observing, experimenting (...), making conjectures, arguing, conclude and evaluate" (p. 164).

This syllabus does not mention investigations but it refers several times the importance of formulating conjectures, one of the key aspects of the investigation process. It is also remarkable the emphasis given to the development of an investigation stance, as well as the attention to argumentation, discussion, discovery and evaluation. Similar references can be found in the syllabus of grades 7-8-9 (Ministério de Educação, 1991b).

In the grades 10-11-12 (secondary school) mathematics syllabus, published more recently (Ministério da Educação, 1997), one of the aims of the discipline is stated as: "to develop the ability to formulate and solve problems, to communicate, as well as memory, rigor, critical spirit and creativity" (p. 3). In the topic concerning the development of reasoning and scientific thinking there is an explicit reference to the need of the student "to validate conjectures" (p. 4). Further ahead, in the section of methodological orientations, one reads: 
Explorations and investigations in the mathematics classroom

The importance of the activities to select stands up, as they must contribute towards the development of scientific thinking, leading the student to develop intuitive perceptions, to conjecture, to experiment, to prove, to evaluate and also to reinforce autonomy and cooperation attitudes. (p. 8)

Concerning resources, the syllabus indicates that the use of graphic calculators allows "conducting mathematical experiences, to develop and test conjectures" (p. 11) and each student must undertake "investigations and explorations of several links among different representations..." (p. 11). The use of computers is encouraged because of its potential for "exploration and investigation activities..." (p. 11). And in the methodological orientations there is an explicit reference to investigation tasks: "in the study of families of functions students may carry out small investigations" (p. 20).

The most recent Portuguese official document, the National curriculum of basic education, refers several aspects of the mathematical competence that students must develop, including reasoning mathematically, searching for regularities, making and testing conjectures and formulating generalizations (Ministério da Educação, 2002). This document emphasizes investigation activities as one of the key learning experiences that must be provided to students.

Therefore, among all Portuguese documents, the National curriculum and the grades 10-11-12 mathematics syllabus make stronger explicit references in recommending that students carry out investigation activities. The other syllabi, without indicating it so clearly, also point towards the importance of mathematical processes associated carrying out this kind of task.

\section{Implemented curriculum}

A national survey carried out by the end of the 1990s (APM, 1998) inquired teachers about the situations that they use more frequently in their classes. Without much surprise, exercises come first in the list: $94 \%$ of teachers at grades 5-6 (2 ${ }^{\text {nd }}$ cycle of basic education), $91 \%$ of teachers at grades 7-8-9 ( $3^{\text {rd }}$ cycle of basic education) and $94 \%$ of grades 10-11-12 (secondary school) indicate to use them always or in many classes. Problems come in second place, with percentages that may be considered quite high, but that decrease with school levels: $80 \%, 77 \%$ and $67 \%$, respectively. Further below appear open and challenging situations that may yield a stronger involvement of students - exploration activities $(18 \%, 12 \%$ and 14\%, respectively) and project work $(1 \%, 2 \%$ and $3 \%$, respectively). In this survey data, the most positive result is the 
Explorations and investigations in the mathematics classroom

reasonable relative weight of problems, but this result must be regarded carefully since the term "problem" may be used by those who responded with rather different meanings. What many teachers regard as a problem, others may consider as an exercise.

At the same time, many teachers report on national meetings experiences involving students doing all kinds of explorations and investigations and indicate to use them regularly in their practices. These experiences concern different grade levels and all mathematics topics (number, geometry, algebra, probability, and statistics). Some involve sets of structured open-end tasks and others concern extended pieces of work, usually carried out in groups. Therefore, for a noticeable group of teachers this seems to be a highly regarded kind of activity. However, for many other teachers explorations and investigations still appear to be a marginal activity to propose in mathematics classes, especially when there is pressure for preparation for external examinations (more strongly at grade 12 but also noticeable at grade 9).

\section{The influence of assessment in the evolving curriculum}

In Portugal, students' learning in mathematics is subject to internal and external evaluations. Internal evaluation is done through the school year by teachers who also give a final mark at the end of the year. Furthermore, there are national exams in mathematics at the end of grades 9 and 12. Failure in these exams has consequences for students, who may have to repeat one academic year or may be subject to restrictions regarding their continuation of studies. At grades 4 and 6 there are exams ("Provas de aferição"), but they only have an "indicative" role regarding students' learning at that grade level, with no consequences for individual students.

The grade 12 exam did not evolve much in the last 20 or 30 years. It addresses the topics of functions and derivatives and also probability (that is studied with a high level formality, as an example of an axiomatic system). This exam serves the purpose of selecting students to enter higher education programs and is very selective. It constrains just about everything that teachers do in grades 10,11 and 12, leaving little room for curriculum innovation other than that clearly focused in the exam features.

The situation is different for "Provas de aferição" for grades 4, 6 and for the exam of grade 9. These exams have been influenced by international assessments such as PISA, and emphasize tasks where realistic contexts play a major role and require 
considerable interpretation and reasoning from students. However, given their time constrains, these exams do not contain open ended or extended tasks. On one side, they reinforce the view that mathematics tasks must be varied beyond classical computational exercises or intricate abstract problems - which is a clear progress regarding the previous style of exams as those that still exist on grade 12. On the other side, they do not accept the notion of extended exploration or investigation and thus do not encourage teachers in proposing these tasks in their classrooms. However, as we have seen, the national curriculum emphasizes the importance of explorations and investigations and the same happens with the draft of the new syllabus for basic education. Textbooks are beginning to present open ended and exploratory tasks as well as tasks that require reflection and higher level thinking.

In so far as the internal evaluation carried out by teachers keeps an important value in the Portuguese school system, there is the possibility that curriculum orientations, better quality textbooks, teacher professional development initiatives and leadership from the professional movement will reinforce the importance of explorations and investigations in the mathematics classroom. The trend, however, is for an increasing weight of external evaluations. If that trend continues, it is more likely that this kind of work will be less and less important in schools. Future developments will show what paths will emerge from these contradictions between and promising research and classroom reports, official curriculum orientations, and the assessment system.

\section{Conclusion}

To be interesting for teachers, the notion of mathematical investigation needs to stand on some sort of legitimacy. One may consider two such kinds of legitimacy. The conceptual legitimacy of the notion of mathematical investigation stands essentially on the testimonial of mathematicians that reflect about their experience of investigating in mathematics. Many of these mathematicians consider that, with the necessary adaptations, mathematical investigations are within the range of what most students are able to do. To do that, naturally, it is necessary to subscribe a wide notion of investigation that values in special the importance of questions and of a questioning attitude and not so much the technical or formal aspects of the investigative activity that 
we find in the practices of the professional researchers. In school mathematics, investigations constitute a kind of task with well-defined characteristics that may be put alongside with exercises and problems. In doing a mathematical investigation one recognizes several moments, such as posing questions, formulating, testing and refining conjectures and justifying them. Especially important is the articulation between investigation and proof, given the central role that proof assumes in the mathematics activity.

The curricular legitimacy of mathematics investigations stands, in the first place, in the written text of the official curriculum documents. In Portugal, as well as in other countries, there is a wide support for this perspective in the official discourse. However, it is not seen as such by many teachers. Furthermore, this is a perspective that is not easy to adjust to the traditional assessment practices, mainly based in tests and written exams. We may say that this perspective moves in a framework of curricular ambiguity, being valued by some groups of teachers and ignored by others. For the students and for the society in general, investigations are an idea that is not much visible, that is accepted or rejected according to the degree of acceptance of innovative educational perspectives and the value ascribed to traditional indicators of mathematics achievement, such as proficiency in numerical or algebraic computation.

In the studies carried out in Portugal, there are many examples that show the great enthusiasm and involvement of students in doing mathematical investigations. This involvement constitutes a fundamental basis for learning. This has been quite well documented regarding the different phases of doing a mathematical investigation in the classroom, concerning several cross curriculum objectives (especially, oral and written communication, the development of autonomy and the capacity of working in groups), as well as regarding changes in students' conceptions. However, specific learning of students in mathematical topics only now is been addressed in a more coherent and deeper way. This is a point that deserves to be further inquired. Also, the movement from testing and refining conjectures to justifying them and producing mathematical proofs requires more attention from researchers.

The problem of integrating investigation activities in teachers' curriculum management practices is the most difficult to handle. Of course, it would be mistaken to reduce all mathematics teaching to investigation and exploration activities. Investigations have a role to fulfil, contributing to achieve some curriculum objectives, but there is no claim that they will enable to achieve all the objectives of the discipline. 
Both the global decisions (What weight to ascribe to different kinds of tasks? How to combine them?) and the local issues (How to introduce investigations? Up to what point carry out their exploration? How and when move to the production of mathematics proofs?) require much more attention.

Another question that research has to face is the issue of large scale implementation. What theoretical frames and methodologies developed to support such development? How can it be monitorized? That is a pressing issue for researchers since a new national curriculum has just been approved and makes a stronger case for explorations and investigations in mathematics classrooms from grades 1 to 9.

In conclusion, extending the curriculum perspective of problem solving and seeking to draw on the potential of information and communication technologies, mathematical investigations seem to be an interesting curriculum perspective for mathematics teaching. The small scale experiences carried out have shown their potential as a basis for the development of several curriculum objectives. However, their role as a support for the development of mathematics knowledge and competence is still to be deeper explored, as well as the issue of how to integrate them in curriculum management practices and how to support large scale dissemination. These are the main challenges presently faced by this line of work in mathematics education.

\section{References}

Abrantes, P. (1988). Um (bom) problema (não) é (só)... Educação e Matemática, 8, 710 e 35.

Abrantes, P. (1994). O trabalho de projecto e a relação dos alunos com a Matemática: A experiência do projecto MAT $_{789}$ (Doctoral dissertation, Universidade de Lisboa). Lisboa: APM.

Abrantes, P., Ponte, J. P., Fonseca, H., \& Brunheira, L. (Eds.). (1999). Investigações matemáticas na aula e no currículo. Lisboa: APM e Projecto MPT.

Amaral, H. (2003). Actividades investigativas na aprendizagem da Matemática no $1 .^{o}$ ciclo (Tese de mestrado, Universidade de Lisboa).

APM (1988). Renovação do currículo de Matemática. Lisboa: APM.

APM (1998). Matemática 2001: Diagnóstico e recomendações para o ensino e aprendizagem da Matemática. Lisboa: APM.

Boavida, A. M. (1992). Resolução de problemas: Que rumos para a educação matemática? Educação matemática: Temas de investigação (pp. 105-114). Lisboa: IIE e SPCE. 
Branco, N., \& Ponte, J. P. (2006). Das regularidades às equações: Uma proposta pedagógica para o 7. ${ }^{\circ}$ ano de escolaridade. In Actas do XV Encontro de Investigação em Educação Matemática (CD-ROM). Encontro de Educação Matemática da Sociedade Portuguesa de Ciências de Educação, 7-9 Maio 2006, Monte Gordo.

Brocardo, J. (2001). Investigações na aula de matemática: A história da Rita. In I. C. Lopes, J. Silva, \& P. Figueiredo (Eds.), Actas ProfMat 2001 (pp. 155-161). Lisboa: APM.

Brocardo, J. (2002). As investigações na sala de aula de Matemática: Um projecto curricular no $8 .^{\circ}$ ano (Tese de doutoramento, Universidade de Lisboa). Lisboa: APM. (disponível em http://ia.fc.ul.pt)

Brunheira, L. (2002). O estágio e o projecto de formação em didáctica da matemática: Uma experiência. In GTI (Ed.), Reflectir e investigar sobre a prática profissional (pp. 189-214). Lisboa: APM.

Candeias, N., \& Ponte, J. P. (2006). Uma proposta curricular para o ensino da geometria do 8..$^{\circ}$ ano. In Actas do XV Encontro de Investigação em Educação Matemática $(C D-R O M)$. Encontro de Educação Matemática da Sociedade Portuguesa de Ciências de Educação, 7-9 Maio 2006, Monte Gordo.

Cunha, M. H. (1998). Saberes profissionais de professores de matemática: Dilemas e dificuldades na realização de tarefas de investigação. (Tese de mestrado, Univ. de Lisboa). Lisboa: APM.

Fernandes, D. (1992). Resolução de problemas: Investigação, ensino e formação de professores, Educação matemática: Temas de investigação (pp. 45-104). Lisboa: IIE e SPCE.

Fonseca, H. (2002). Aprender a ensinar Investigando. In GTI (Ed.), Reflectir e investigar sobre a prática profissional (pp. 177-188). Lisboa: APM.

Frank, M. L. (1988). Problem solving and mathematical belief. Arithmetic Teacher, 35, 32-34.

Garofalo, J. (1989). Beliefs and their influence on mathematical performance. Mathematics Teacher, 82(7), 502-505.

Godinho, R. (2007). As actividades de investigação em educação matemática num contexto inclusivo no $1^{\circ}$ ciclo do ensino básico (Tese de mestrado, Universidade de Lisboa).

Gravemeijer, K. P. E. (2005). What makes mathematics so difficult, and what can we do about it? In L. Santos, A. P. Canavarro \& J. Brocardo (Eds.), Educação matemática: Caminhos e encruzilhadas (pp. 83-101). Lisboa: APM.

Hadamard, J. (1945). Psychology of invention in the mathematical field. Princeton, NJ: Princeton University Press.

Henriques, A., \& Ponte, J. P. (2006). Actividades investigativas e aprendizagens na Análise Numérica. In Actas do XV Encontro de Investigação em Educação Matemática (CD-ROM).

Junqueira, M. (1996). Exploração de construções geométricas em ambientes computacionais dinâmicos. Quadrante, 5(1), 61-108. 
Explorations and investigations in the mathematics classroom

Krainer, K. (1993). Powerful tasks: Acontribution to a high level of acting and reflecting in mathematics instruction. Educational Studies in Mathematics, 24, 65-93.

Mason, J., Burton, L., \& Stacey, K. (1982). Thinking mathematically. London: AddisonWesley.

Matos, A., \& Ponte, J. P. (2006). O estudo das relações funcionais como suporte do desenvolvimento do pensamento algébrico: Uma investigação com alunos do $8 .^{\circ}$ ano. In Actas do XVII SIEM - Seminário de Investigação em Educação Matemática.

Ministério da Educação (1991a). Organização curricular e programas - $2^{\circ}$ ciclo do ensino básico (volume I). Lisboa: Imprensa Nacional.

Ministério da Educação (1991b). Organização curricular e programas $-3^{\circ}$ ciclo do ensino básico (volume I). Lisboa: Imprensa Nacional.

Ministério da Educação (1997). Matemática: Programas - 10 $11^{\circ}$ e 12 anos. Lisboa: Editorial do Ministério da Educação.

Ministério da Educação (2002). Currículo nacional do ensino básico: Competências essenciais. Lisboa: Ministério da Educação, Departamento de Educação Básica.

NCTM (1980). An agenda for action. Reston, VA: NCTM.

NCTM (1989). Curriculum and evaluation standards for school mathematics. Reston, VA: NCTM.

NCTM (2000). Principles and standards for school mathematics. Reston: NCTM.

Nohda, N. (1991). Paradigm of the 'open-approach' methods in mathematics teaching: Focus on mathematical problem solving. ZDM, 91(2), 32-37.

Oliveira, H. (1998). Vivências de duas professoras com as actividades de investigação. Quadrante, 7(2), 71-98.

Perez, F. (2002). Investigando sobe a prática na formação inicial de professores. In GTI (Ed.), Reflectir e investigar sobre a prática profissional (pp. 215-234). Lisboa: APM.

Pólya, G. (1945). How to solve it: A new aspect of mathematical method. Princeton: Princeton University Press.

Ponte, J. P. (1992). Concepções dos professores de Matemática e processos de formação, Educação Matemática: Temas de Investigação (pp. 185-239). Lisboa: IIE.

Ponte, J. P. (2001). Investigating in mathematics and in learning to teach mathematics. In T. J. Cooney \& F. L. Lin (Eds.), Making sense of mathematics teacher education (pp. 53-72). Dordrecht: Kluwer.

Ponte, J. P., \& Abrantes, P. (1982). Os problemas e o ensino da matemática. In Ensino da Matemática: Anos 80 (pp. 201-214). Lisboa: SPM.

Ponte, J. P., Brocardo, J., \& Oliveira, H. (2003). Investigações matemáticas na sala de aula. Belo Horizonte: Autêntica.

Ponte, J. P., Ferreira, C., Brunheira, L., Oliveira, H., \& Varandas, J. M. (1998). Investigating mathematical investigations. In P. Abrantes, J. Porfirio, \& M. Baía 
Explorations and investigations in the mathematics classroom

(Eds.), Les interactions dans la classe de mathématiques: Proceedings of the CIEAEM 49 (pp. 3-14). Setúbal: ESE de Setúbal.

Ponte, J. P., \& Matos, J. F. (1992). Cognitive processes and social interaction in mathematical investigations. In J. P. Ponte, J. F. Matos, J. M. Matos \& D. Fernandes (Eds.), Mathematical problem solving and new information technologies: Research in contexts of practice (pp. 239-254). Berlin: Springer.

Ponte, J. P., Matos, J. M., \& Abrantes, P. (1998). Investigação em educação matemática: Implicações curriculares. Lisboa: IIE.

Ponte, J. P., Oliveira, H., Brunheira, L., Varandas, J. M., \& Ferreira, C. (1998). O trabalho do professor numa aula de investigação matemática. Quadrante, 7(2), 41-70.

Ponte, J., Oliveira, H., Cunha, M., \& Segurado, I. (1998). Histórias de investigações matemáticas. Lisboa: IIE.

Segurado, I. (1997). A investigação como parte da experiência matemática dos alunos do 2. ${ }^{\circ}$ ciclo (Dissertação de Mestrado, Universidade de Lisboa). Lisboa: APM. (disponível em http://ia.fc.ul.pt)

Segurado, I. (2002). O que acontece quando os alunos realizam investigações matemáticas? In GTI (Ed.), Reflectir e investigar sobre a prática profissional (pp. 57-73). Lisboa: APM.

Segurado, I., \& Ponte, J. P. (1998). Concepções sobre a Matemática e trabalho investigativo. Quadrante, 7(2), 5-40.

Silvestre, A. I., \& Ponte, J. P. (2006). A aprendizagem da proporcionalidade apoiada em tarefas de investigação, problemas contextualizados e no uso das TIC. In Actas do XV Encontro de Investigação em Educação Matemática (CD-ROM). Encontro de Educação Matemática da Sociedade Portuguesa de Ciências de Educação, 7-9 Maio 2006, Monte Gordo.

Skovsmose, O. (2001). Landscapes of investigation. ZDM, 33(4), 123-132.

Sullivan, P. (1999). Seeking a rationale for particular classroom tasks and activity. Paper presented at the Mathematics Education Research Group of Australasia, Adelaide.

Wittmann, E. C. (1995). Mathematics education as a 'design science'. Educational Studies in Mathematics, 29, 355-374. 